\title{
Gender Discourse in 20th Century Indian Short Story Writers
}

\author{
Dr. Mukesh Yadav \\ Assistant Professor, College of Sciences and Arts, Al Qurayat, Al Jouf University, Saudi Arabia \\ *Corresponding Author: Mukesh Yadav, Assistant Professor, College of Sciences and Arts, Al Qurayat, \\ Al Jouf University, Saudi Arabia
}

\begin{abstract}
The present paper looks at how Gender discourse is worked out and postured by Indian ShortStory writers in English and more specifically how gender brings about difference in discourses about the narrative structuring that women have made the most recognizable contribution by differentiating themselves from not only the prescribed tradition of genre but also from the strategies used by men. A gradual weaning can be seen from linear narratives that had enabled women to carve out a safe space for themselves by creating typical 'feminine text' of domestic bliss and fantasies. Women in their short stories most often than not use the debunking rhythm and the stories begin at the end have dramatic suspense and remain openended. Men atleast in the short story form are not given to such experimentation. Such issues of narrative structures have chiefly been focused upon while analyzing how being a man or woman brings about a difference in narration in short stories written in English.
\end{abstract}

Keywords: Gender, Narrative Structures, Feminist, Indian Short -Story Writers

The respectable position and rights equal to men, which were enjoyed by Indian woman in the Aryan age, were destroyed and the condition of women deteriorated right through the middle ages upto the Imperial rule. The social reforms of early twentieth century removed the tyranny of social evils but subordination still lingered on in the society. So a few educated women held the banner for emancipation and communicated to the world their own bitter experiences through their writings. "They tried to tell the world the obstacles women faced and the disadvantages they suffered in an orthodox Hindu world. These women writers struggled to give form and shape to their autobiographical accounts, which attracted publishers, both in India and abroad" opined another feminist.

Change is the essence of life. Literature the mirror of life, keeps reflecting the changing images of life. With the changes in society the life of women has simultaneously undergone changes. Analyzing the change sociologist observes: "With a change in women's personal status and social status has come a change in her way of thinking and feelings and the past half century has witnessed great changes in attitude towards sex, love and marriage." The earlier writers presented the traditional Sita image, a submissive, pitiable character. With changed times, the new woman has replaced her traditional, virtuous counterpart. The realistic image of woman with her sense of frustration and alienation is presented in modern women's writing. Nayantara Sehgal tries to create the virtuous woman- the modern Sita, if you like. My women are strivers and aspirers, towards freedom, towards goodness, towards a compassionate world. Their virtue is a quality of heart and mind and spirit, a kind of untouched innocence and integrity.

The conflict created by the tradition from the old to the new, by the opposing forces of modernity and tradition, conflict between emotion and reason has become the subject for the Indian writers. Indian women writers are discovering innovative patterns of asserting female self-hood, forming a new feminist consciousness in keeping with changed times and showing increasing courage in breaking age- world strictures regarding woman's existence. There is a shift from victim feminism to power feminism.

Women's literature reflects contemporary conditions and situations of the society, current issues, popular concepts and also bears the impact of writer's class and creed. In the forties and fifties, the context of women's literature was the major reorientation in the social imaginary that took place as 
India became a democratic state and as the new movements of opposition emerged in the seventies. Women's texts challenge the new authorities, but also often help consolidate the protocols of power.

Some of the prominent women writers of $20^{\text {th }}$ Century India who have inspired, redefined the lives of women and created new life patterns are Ismat Chugtai, Rasheed Jahan, Amrita Pritam, Anita Desai, Shashi Deshpande, Bharti Mukherjee, Shivani, Mahasweta Devi, Mrinal Pandey, Nayantra Sahgal, Attia Husain, Nergis Dalal, Ruth Prawer Jhabvala, Mannu Bhandari and Jaya Mehta constitute the significant group of Indian women writers in English.

Indian women writers do hold a respectable position in the west but they have not been given the same critical respect like their male counterparts in their own country. To establish themselves they have to combat with certain critical prejudices; one of these is gender-based since they write about the enclosed domestic space and a woman's perception of experience through her position in it, it is patriarchal assumption that their work will rank below the works of male writers who deal with weightier themes. Secondly, their regional counterparts are prejudiced against them. Since English belongs to the upper and economically affluent classes, the general impression is that the writers and their works are cut off from the reality of Indian existence. The depiction of the frustrated housewife in the short stories of Anita Desai or Shashi Deshpande might seem utterly superficial when compared to the oppressed lives of women of the lower classes in the works of Mahasweta Devi. But to ignore this element of cultural class would destroy the variety vital for a healthy literary climate in any country.

The Indian women short story writers have attempted to portray complex human relationships aiming at bringing out the essential India contextualized in the picture of a variegated and colourful India. They have exhibited a common feminist concern for the women of India. Their concern is to write about women and their struggle "in the context of contemporary Indian society, to find and preserve her identity as wife, mother and most of all as human being."

One charge, which is often made against women's writings, is that it is very subjective, limited and restricted in its depth and scope. In India as elsewhere, men's writing is often privileged over that of women for it is felt that the latter's world is inside and is very narrow and constrained, while the formers is outside broad and hence, has a greater value and relevance. Further male writing is universal, while women's writing is not. So in order to be accepted, a woman must "write like a man." Contemporary women writers protest against such chauvinistic attitude and phallocentric approach. A male writer says that if I am born with that sex can I write as other than what I am?

So, the first step in feminist literature is to assert women's point of view because both men and women are looking at the same landscape but "from contrasting vantage points", hence the same scene can appear very different to them. Though men and women may narrate the same reality, the same experience, yet the views, the explanations, the images and comparisons are different and so also the perceptions and perspectives.

To assert the feminine is to subvert the male norm. The first step in this task is to dismantle the images of woman created by man, the dominant of which is the self-sacrificing mother and wife. Indian women writers working in the feminist tradition rebel against this projection. Uprooting it became one of the most important tasks of the women writers. Virginia Woolf (1979) aptly observes "Killing the Angel in the House was a part of the occupation of a women writer" (60). In the context of Indian ethos this task acquires a great importance, for women is reduced by the tradition to a sacrificial cow.

It is surprising to know that women took to writing and through it they have expressed themselves and have presented an explicit comment on the situation of women in contemporary society combating with restrictions imposed upon them by the traditional, male dominated patriarchal society, or to adhere to culturally approved behviour and in the course effacing their own existence. Occasionally, the heroines are presented as relaying upon extreme remedies to untangle their inner conflict, at times they give in to social pressures imposed upon them by the environment -female writers have employed the narrative to bring to notice the issues concerning deprivation of married women, their exploitation, their endurance, their silences, and their problems. Nafisa Hatimi (2000) in her paper 'Conflict and Violence' in Shashi Despande's "The Intrusion" and Bharati Mukherjee's "A Wife's Story" states: "The contemporary narrative of Indian women writers reveals the conflicts that women 
undergo while facing the trials of life as victims, marginalized and bound to their psychological ghetto. An important concern of Indian women's fiction is related to the portrayal of women struggling for emancipation and facing identity crisis" (195).

The psychological tensions that women undergo are dealt with in the narratives and there is a realistic portrayal of the reactions and the out come of the tensions. The stories also trace out how the emotional vaccum becomes the cause of mental and sexual agony.

Namita Gokhale (2002) questions: "Do women write differently from men? Do these constitute parallel literatures? Are the critical yardsticks different?" (65). She believes that "it is necessary to document the internal conflict of the feminine psyche, with its conflicting and contrary expectations, this should not become an obsessive internal exercise. Of course women are obsessed with their sexuality because this is an area in which they have been repressed" (66).

Man and woman are inter-related, they both share some of each other's characteristics but when it comes to writing women circumscribe themselves to domesticity and its oppressions, biology and its outrages, the dimensions of love and lack of it.

Rajul Bhargava (2002) holds: "Narrating is never an innocent act and the narratives that frame a situation allow writers to dramatize the results of the telling" (77). Literature is consequential and the tail told reacts on the life of the reader. This genre is employed to renegotiate the ideologies of gender inequalities. Though it is on small scale, it is focused and concentrated, can expand inwards, questioning the prevailing norms and structures in her words. "The surface smoothness of the short narrative is a balancing act like that of the tight rope walkers who do seen to glide ever so smoothly and with ease but from within each muscle aches and each sinews goes taut. The balancing act is between the 'said' and 'unsaid' the narrator believing that it is better to say 'not enough' than to say 'too much'.

The short story is small in form yet it encompasses the feminist attitudes. The narrative frame may be thin but at the centre there is dense motif.

The smallness and power of this genre has attracted many women writers to make use of it. Indian novelists like Shashi Deshpande, Dina Mehta, Anita Desai, Bhart Mukherjee, Bhisam Sahani, Rajinder Ssingh Bedi, Vikram Seth have discovered its potentialities to assault, wrench and disrupt.

Shashi Deshpande and Bharti Mukerjee began their writing career with short stories. Both have endeavored to trace the conflicts and the outcome of the differences arising in this conflict on the psyche of Indian women. Shashi Deshpande has emerged as one of the mainstream women writers in India and has drawn critical attention because of her detailed, sensitive and realistic representation of Indian middle class woman in her domestic sphere. Her fiction specially her short stories, explore the conflict that women undergo while fulfilling their traditional roles as daughter, wife and mother. While Shashi Deshpande deals with a typical native scene, Bharti Mukherjee presents the picture of a woman struggling to keep herself intact in an alien land.

The subordinate positioning of the female sex in a male dominated society is the chief theme with the male as well as the female short story writers. But they perceive even the same subject differently. Female writers have poured their experiences and thoughts in their short stories in varied ways by bringing in oral histories, traditions, female memories and bodily experiences. They have portrayed Indian women trapped in the overlapping circles of household responsibility, social expectations and feminity. Sarla, the central character in Anita Desai's story 'Royalty' wavers between an intense desire to exercise her freedom and the sense of responsibility as a hostess. In the short stories by female writer gender relations and gender roles underline the oppressive nature of human society in which women are denied the freedom to act independently and their voices stifled by male egocentredness and unconcern. These women characters realize the painful truth that "involvement is enslavement and the loss of freedom, while detachment and stillness, beside being equally destructive appear to be attainable" (Jain 35). Female short story writers are not interested so much in registering surface realities as in the probings of inner truths lying under the surface level. Their range is wider in the sense that it is not limited to a portrayal of outward life, but includes a psychological study of the character. Anita Desai's short stories such as "Games at Twilight", "PineApple Cake" and "Studies in the park" ; Shauna Singh Baldwin's "Family Ties" are studies in child psychology. Moreover, Anita Desai delineates characters not only of normal human beings but also of abnormal ones, such as that 
of Harish, in "Surface Textures" who has a mania for gazing at and feeling surface texture of things. She also portrays the eccentricities of old age in "The Devoted Son". In order to present the submerged psychic truth Anita Desai has employed various linguistic devices like clusters of images, symbols and myths; fresh collocations, deviations and parallelisms. She exploits even phonological patterns like alliteration, assonance, consonance, rhyme etc. Different levels of semantic interpretations also become significant for the presentation of her characters. Anita Desai herself says that though "the minor characters" she has "picked from real life," "I don't think any of the major characters in my books are taken from real life. They are entirely imaginary or an amalgamation of several different characters.

The Indian women short story writers have attempted to portray complex human relationships aiming at bringing out the essential India, contextualized in picture of a variegated and colourful India. Their, specially Anita Desai's use of Indian words is restricted mostly to the names of Indian dishes, dresses, games and certain other things which cannot be expressed with precision by using their English equivalents. One of the most outstanding things in Anita Desai is the use of parenthesis, which she does for explanation, modification, comment and reflection. Verbose style is to be traced to Desai's heavily adjective style. Shiv K. Kumar (1982) commenting on her style says: "the sentences meander on, as usual, in response to some inscrutable rhythm, tapering off into mere nothingless." (191-192)

As there is an absence of absorbing experience to be communicated the language of communication and the diction and the sentence structures are all mechanical. There is a strong suggestive element in the stories of male writers, which links them with the mainstream of the Indian tradition and brings out the Indianness in their stories.

Metaphor and mythical elements are of basic importance in the art of male writers like that of Bedi. Quite often the inner structures of his stories are based o allusions drawn from the ancient Indian pantheon. But at the same time it would be far from correct to infer that Bedi consciously raised the superstructure of his stories on these foundations. Evidently, there is something spontaneous about these stories for the structures evolve themselves as if on their own, taking a cue from these mythological allusions. Bedi's creative process seems to be something like this: he tries to delve into the fathomless mysteries and secrets of life through the psychological build up of his characters. $\mathrm{He}$ does not look at the natural disposition of man, his instincts, the carnal demands of his body, the spiritual urges of his soul at their superficial conscious level. On the other hand, he goes to their subconscious depths, which have the ring of centuries behind them. In Bedi's writing an event is just not an isolated event but it is a link in an unbroken chair of numberless events, all carried forwards in one sweep. Since in this creative process his journey is from the concrete to the abstract, from the vent to the limitlessness of action, from the finite to the finite or from the mundane to the metaphysical, he again and again resorts to the metaphor, symbolism, mythology and copious references to the Indian pantheon. In this respect Bedi's creative process is very different from Krishan Chander's and Manto's.. Krishan Chander essentially remains at the surface; Manto has the penetrating eye to look behind the events. But Bedi is different from them in as much as, though his feet remain planted on terra firma his head soars in the sky.

Bedi's style is complex and thought provoking. His similes are not single or double but many faceted and his characters are multi-dimensional whose one aspect is real and other archetypal. It is evident in his creative process, that time and space has no bearing in the conventional sense. Bedi's man and women are not bound down to the present time but they represent the primeval men and women who have been undergoing human suffering since aeons and simultaneously enjoying the boon provided by this earth. Due to Bedi's multitudinal metaphors, the problems, loves, hates, joys and sorrows of his characters are not just their own individuals but in them one can also see the sufferings of mankind and the feelings and emotions which have been man's lot from time immemorial. These metaphysical overtones which lend his stories a kind of universality are the main characteristics of Bedi's art. In the story "Lajwanti", Bedi has drawn upon the episode of the washerman and the fate of Sita in the Ramayana; In "Jogia", he has played upon a range of colours to create psychological effects; In "Bulbul" to save the honour of the female character he has associated her name with Sita.

In the short stories of Premchand one finds a basic ruggedness of style while in Manto it manifests itself in its most chiseled form, free from pedestrian unevenness or surfeit. In Manto one does not find a single superfluous word. From the point of view Manto's style is a high watermark of brevity. As 
against that Krishan Chander is over generous in the use of words; in his prose one finds an unimpeded flow of words, marked by adroitness and agility. But the effect of his magic does not last long. Soon it starts to create the effect of superficial gloss.

From the very beginning Bedi realized that he could not write florid and picturesque prose like Krishan Chander nor deal with sex with the same uninhibited boldness as Manto. Whatever he wrote, he wrote with great care after weighing each word. Once Manto had a dig at him, "you think too much," he said to Bedi. "You think before you write. You think while you are writing and also after you have finished writing." On account of his obsessive thinking what he lacked in spontaneity he more than made up by using the language creatively with its attendant graces.

The habit of finding the inner meaning in the outer reality gradually took the male writers into the realm of suggestion, symbolism, metaphor and allusion- in other words, the highly creative use of language. In Rajinder Singh Bedi's story, "Rahman's Shoes", the fact of one shoe overriding the other is a portent of a journey in the offing. This journey can be from one place to another in the physical sense and also a journey to death in the spiritual sense. But it is the story "Grahan" (Eclipse), in which Bedi has run the full gamut of a metaphor. Here he has blended a myth into a plot so as to transpose them into one another. Here we have the lunar eclipse and running parallel to it we have the earthly phenomenon of a similar nature happening to a woman; her fate too is under an eclipse.

Unique in delineation of female characters, Bedi deals with them with a Buddha like compassion. His mind dwells more on the woman than on man and the feminine or the matriarchal element in the primeval beginnings of mankind fascinates him. In his story "Give me Your Sorrows". Madan is only a means, an instrument in the process of creation. Indu is the subject, the cardinal factor that acts while Madan is the object, the one who is acted upon.

Bedi held his readers enthralled by the use of most just virtuosity and grip on the realities of life. People read him for pleasure, for illumination and for an insightful understanding of life. Not standing for any "isms" he stood for the entire humanity.

Among the contemporary short story writers there are some who inspite of flavorings the fstyles of direct expression in bulk of their writings have also used the oblique or the allegorical style in some of their stories. In the new fiction symbolism and allegorical expression have assumed that dimensions of a major trend. Intizar Husain's style can be called the extension or offshoot of the style of the traditional fable or allegory while Bedi's style has a mythological ring. There are some short story writers who attach great importance to literary embellishments such as purple patches, florid expression and similes coming thick and fast in their writings.

The female writers are subjective, limited and restricted, while the male writers are more objective in their writings. The female writers in their short stories have poured domestic experiences by bringing in oral histories, traditions and female memories. Female short story writers are not interested so much in registering surface realities as in the probing of inner truth lying under the surface level.

This basic difference that is found in the style of male and female writers is natural. As by nature women are more emotional and sensitive while men are more practical and calculative. The findings of this study have revealed that apart from several factors gender also plays an important role in determining these differences.

\section{REFERENCES}

[1] Baldwin, Shauna Singh: "Family Ties" in Shauna Singh Baldwin's English Lessons and Other Stories. India: Harper Collins Publishers, 1999.

[2] Baldwin, Shauna Singh : "What the Body Remembers" India. Harper Collins Publishers, 1999.

[3] Bedi, Rajinder Singh : 'Introduction' in Rajinder Singh Bedi's "Selected Short Stories". New Delhi: Sahitya Academy,1989.

[4] Bedi, Rajender Singh. "Lajwanti" in Saros Cowasjee \& K.S.Duggal (ed.) Orphans of the Storm: Stories on the Partition of India. New Delhi: UBSPD Ltd., 1995.

[5] Bennett, T. Outside Literature. London;Routledge.1990.

[6] Bhabha, H.K. 'Dissemination: Time, Narrative and the Margins of the Modern Nation' in H.K.Bhabha (ed.) Nation and Narration, London: Routledge, 1990.

[7] Bhargava, Rajul (Ed.) 'Indian Writing in English: The Last Decade.’ Jaipur: Rawat Publications, 2002. 
[8] Bhatnagar, Manmohan K. (ed.) : Indian Writings in English Vol. I, New Delhi:Atlantic Publishers and Distributors, 1996.

[9] Chander, Krishna. "Peshawar Express" in Saros Cowasjee and K.S. Duggal (Ed.) Orphans of the Storm: Stories on the Partition of India. New Delhi: UBSPD, 1995.

[10] Desai, Anita: Diamond, Dust and Other Stories, London, Vintage, 2001.

[11] Desai, Anita: Games at Twilight and Other Stories, London, Vintage, 1998.

[12] Deshpande, Shashi: 'The Intrusion and Other Stories, New Delhi: Penguin Books, 1993.

[13] Gokhale, Namita 'Gender and Literary Sensibility' in Rajul Bhargava (Ed.) 'Indian Writing in English: The Last Decade. Jaipur: Rawat Publications, 2002.

[14] Hariharan, Githa: The Art of Dying, New Delhi: Penguin Books. 1993

[15] Hatima, Nafisa: “Conflict and Violence in Shashi Deshpande's 'The Intrusion' and Bharti Mukherjee's 'A Wife's Story' in Jasbir Jain and Supriya Agarwal (Ed.) "Gender and Narrative" Jaipur: Rawat Publications, 2002.

[16] Jain, Jasbir. 'Gender and Narrative: An Introduction' in Jasbir Jain and Supriya Aggarwal (ed.) "Gender and Narrative". Jaipur: Rawat Publications, 2002.

[17] Kumar, Shiv K. "Art and Experience : A note on Anita Desai as a short story writer" in The Twofold Voice: Essay in Honour of Ramesh Mohan, ed. By Rizvi, 1982.

[18] Malak, A.,Insider/Outsider Views of Belonging: The Short Stories of Bharti Mukherjee and Rohinton Mistry, Short Fiction in the New Literatures in English. Nice: Fac. Des Letters and Sciences Humaines, 1989, III.

[19] Mistry, Rohinton “Tales from Firozsha Baag, New Delhi: Pengun, 1987.

[20] Mukherjee, Bharti. The Middleman and Other Stories. New York: Penguin, 1989.

[21] Woolf Virginia ‘A Room of One’s Own 1929’ Flamingo: Harper Collins Publishers, 1979.

\section{AUTHOR's BIOGRAPHY}

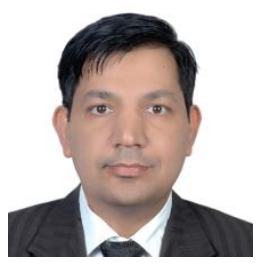

Dr Mukesh Yadav is currently working as Assistant Professor in Al Jouf University, Kingdom of Saudi Arabia. He has extensive expertise in Diasporic Writing and Cross-Cultural education. He has authored four books in the field of language and literature. He has published ten articles in referred journals. He has ten years of progressively responsible teaching experience at the University level in India, Libya and Saudi Arabia.

Citation: Mukesh Yadav, "Gender Discourse in 20th Century Indian Short Story Writers." International Journal of Humanities Social Sciences and Education (IJHSSE), vol 4, no. 10, 2017, pp. 31-36. doi:http://dx.doi.org/10.20431/2349-0381.0410004.

Copyright: (C) 2017 Authors. This is an open-access article distributed under the terms of the Creative Commons Attribution License, which permits unrestricted use, distribution, and reproduction in any medium, provided the original author and source are credited. 